IZA DP No. 7361

Works Councils, Quits and Dismissals in Germany

Christian Grund

Andreas Schmitt

April 2013

Forschungsinstitut

zur Zukunft der Arbeit

Institute for the Study

of Labor 


\title{
Works Councils, Quits and Dismissals in Germany
}

\author{
Christian Grund \\ RWTH Aachen University \\ and IZA
}

Andreas Schmitt

RWTH Aachen University

\section{Discussion Paper No. 7361 \\ April 2013}

IZA
P.O. Box 7240
53072 Bonn
Germany

Phone: +49-228-3894-0

Fax: +49-228-3894-180

E-mail: iza@iza.org

Any opinions expressed here are those of the author(s) and not those of IZA. Research published in this series may include views on policy, but the institute itself takes no institutional policy positions. The IZA research network is committed to the IZA Guiding Principles of Research Integrity.

The Institute for the Study of Labor (IZA) in Bonn is a local and virtual international research center and a place of communication between science, politics and business. IZA is an independent nonprofit organization supported by Deutsche Post Foundation. The center is associated with the University of Bonn and offers a stimulating research environment through its international network, workshops and conferences, data service, project support, research visits and doctoral program. IZA engages in (i) original and internationally competitive research in all fields of labor economics, (ii) development of policy concepts, and (iii) dissemination of research results and concepts to the interested public.

IZA Discussion Papers often represent preliminary work and are circulated to encourage discussion. Citation of such a paper should account for its provisional character. A revised version may be available directly from the author. 
IZA Discussion Paper No. 7361

April 2013

\section{ABSTRACT}

\section{Works Councils, Quits and Dismissals in Germany}

We examine the relationship between works councils and two different types of employment separation: dismissals by the firm and voluntary quits by employees. Based on representative data from the German Socio-Economic Panel, we find a negative relationship between works councils and both kinds of separation. This is particularly true for skilled blue collar as well as qualified white collar workers compared to employees in other job categories. Additionally, we find first hints for a positive relation between works councils and the relevance of severance payments in the case of dismissals.

JEL Classification: M5, J6

Keywords: dismissal, employment separation, quit, severance pay, works council

Corresponding author:

Christian Grund

RWTH Aachen University

Department of Business and Economics

Templergraben 64

52056 Aachen

Germany

E-mail: christian.grund@rwth-aachen.de 


\section{Works Councils, Quits and Dismissals in Germany}

\section{Introduction}

The stability of employment relationships is an important issue for both employees and firms. On the one hand, employee quits cause problems for firms through vacancies, so that retention is a frequent objective. On the other hand, dismissals in the form of firm-initiated separations can lead to dramatic monetary and non-monetary problems for the individuals concerned. In many countries, the decisions of firms and/or employees are supposed to be affected by institutions such as works councils. Works councils act at the establishment level and are endowed with various opportunities of participation, ranging from simple information rights to extensive codetermination rights. In Germany, works councils have considerable bargaining power derived from the Works Constitution Act (WCA), which can be applied to voluntary quits and to dismissals. While works councils have no direct impact on voluntary quits, they may use their participation rights regarding other issues in order to have an indirect influence on voluntary quits. In contrast, works council may have a direct influence on dismissals. $^{1}$

Previous work has examined the relationship of works councils and employment separations in general, but has abstained from a direct distinction between quits and dismissals. Early studies have relied on cross-section data from establishment surveys and tended to find a negative relationship between the existence of works councils and the separations rates in firms (e.g. Frick 1996, Backes-Gellner et al. 1997, Addison et al. 2001, Dilger 2002, Frick \& Möller 2003, Pfeifer 2007). Panel estimations of firm-level data suggest that job security,

\footnotetext{
${ }^{1}$ There is also a literature on other consequences of works councils for firms and employees, such as firms' productivity, investments and growth, or employees' wages and job satisfaction (e.g. Addison et al. 2001, Zwick 2004, Wagner et al. 2006, Kraft \& Lang 2008, Jirjahn 2010, Addison et al. 2010, Grund \& Schmitt 2013).
} 
measured as the expected increase in establishment size, is not associated with the foundation of a works council (Beckmann et al. 2010). Two studies incorporate the employee perspective by using longitudinal linked employer-employee data (Boockmann \& Steffes 2010, Hirsch et al. 2010). Boockmann \& Steffes (2010) investigate determinants of job duration for male employees in Germany. Accounting for firm fixed effects, empirical results exhibit that works councils are negatively related to transition, both into unemployment and into new employment. Distinguishing between subgroups of employees (but not types of transition), the relation holds true for skilled blue collar workers in particular, but not for white collar workers. Hirsch et al. (2010) show that the negative relation between the existence of works councils and separation rates is more pronounced for male employees. These studies do not distinguish directly between quits and dismissals, though.

This paper adds to the relationship between works councils and personnel separations and aims to provide a contribution on an individual data basis. Data from the German SocioEconomic Panel (GSOEP) for the years 2001 and 2006 are used. In contrast to previous studies, the impact of works councils is examined on individual dismissals and voluntary quits respectively. We also have a look at the relevance of severance payments for dismissed employees. Since certain groups of employees may benefit from a works council's existence more than others, it is also analysed whether subgroups of employees with respect to sex (men vs. women) and occupational status (different groups of blue collar and white collar workers) are affected in particular.

The remainder of this paper will proceed as follows: Based on the institutional background and theoretical considerations, we derive hypotheses for the relationship between works councils and both individual dismissals and voluntary quits in general and for certain subgroups of employees in section II. Then, data, variables and the methodology will be described in section III before we present and discuss the results in section IV. Section V concludes. 


\section{Institutional Background, Theoretical Considerations and Hypotheses}

The rights of German works councils are laid down in the Works Constitution Act (WCA). According to this law, works councils can be set up in all establishments with five or more permanent employees. They have to be initiated by the employees themselves. As a consequence they are not present in all appropriate establishments. The actual presence of works councils depends on characteristics such as firm size, firm age and sex composition of the workforce (Addison et al., 2003). In contrast to German unions, which bargain at the industry level, works councils act at the establishment level and are not entitled to call a strike. The WCA does not allow wage negotiations, in order to limit distributional conflicts on the establishment level. However, works councils may use their extensive information and consultation and codetermination rights for many other issues in order to pursue rent-seeking activities.

Works councils have extensive codetermination rights in what are called "social matters", including the introduction of new payment methods or new technologies designed to monitor employee performance, the regulation of working time as well as health and safety issues. Also, works councils are equipped with consultation rights in areas such as manpower planning and changes in work processes, the working environment and job content. Their participation rights concerning financial and economic matters are limited to information provision. Works councils may therefore use these rights for employees' well-being and employee retention.

Works councils are also endowed with substantial consultation and consent rights with respect to individual dismissals. Every dismissal has to be discussed with the works council. This includes the firm having to provide reasons for a dismissal to the works council. If an employer fails to consult the works council, the dismissal is legally null and void (§ 102 (1) WCA). Works councils may give their consent, remain silent, express their misgivings or put forward a contradiction. A works council is required to consult the employees in question before it takes a stand, if this is deemed necessary ( $§ 102$ (2) WCA). A works council can oppose a dismissal if the employer has either disregarded or failed to take social aspects sufficiently into account. Moreover, a works council can object to a dismissal if the employee 
could be kept on in another job within the same firm or in another plant or branch of the same company. A works council can also object to a dismissal if the employee could be kept on after a reasonable amount of further training or after amending certain terms of the contract ( $\S$ 102 (3) WCA). The opinion of the works council is not binding for the employer, though. If the works council has lodged an objection, the employee is entitled to continued employment until a final judgment or a settlement has been made ( $§ 102$ (5) WCA). In the case of wrongful dismissal from a court's view, employees have the right to reinstatement. Since further cooperation between employee and employer is not to be expected, the court can dissolve an employment contract and obligate an employer to pay a financial compensation in terms of a severance payment. ${ }^{2}$

Furthermore, the employer has to inform the works council of any proposed alterations that may include substantial disadvantages to the workforce or a large part thereof. This includes both the timetable for the implementation as well as the number of affected employees ( $§ 111$ WCA). In the case of a collective dismissal, the employer is obliged to pay compensation to the affected employees. According to $\S 112$ WCA, an employer has to negotiate a social plan in firms with more than 20 employees at the request of a works council. If the employer and the works council do not reach an agreement concerning a social compensation plan, both may ultimately submit the case to a conciliation committee. Besides the financial burden on the company, the conciliation committee has to take social criteria into account when making its decision. As compensation for any financial disadvantages, such as an income reduction or loss of firm pension schemes, an employee will receive a severance payment.

This characterization of the institutional background indicates that German works councils are endowed with substantial bargaining power which may affect dismissal decisions of firms and also employees' decisions to quit their jobs.

\footnotetext{
${ }^{2}$ However, it has to be noted that a court decision is not necessary to secure a severance payment. Employers usually aim to avoid such court procedures, because they are worried about their reputation (Grund, 2006). Both parties can reach a mutual agreement, including severance payments, with the help of a court but without any official decision. Hence, employees will be offered a severance payment if they agree to a termination of their employment contract.
} 
Due to their specific consultation and consent rights in the case of individual dismissals, works councils can prevent or at least delay dismissals. Works councils are supposed to act as safeguards against employer opportunism and as protectors of employees' rents (BackesGellner et al. 1997). If deferred compensation in the sense of Lazear $(1979,1981)$ is relevant, works councils may prevent firms’ opportunistic behaviour in terms of terminating long-term employment relationships (Jirjahn 2009), for instance.

Works councils may also foster the formation of internal labour markets and human capital investments (Ellguth, 2006) and therefore reduce dismissal rates indirectly. Due to rising investments in firm-specific human capital, firms do not have to poach employees from other firms within the same sector. Besides, Pfeifer (2010) argues that internal labour markets and promotions serve as an instrument to allocate employees more efficiently. Since firms learn more about employees' abilities and working attitudes, information asymmetries will be reduced and a better job matching will follow.

Moreover, dismissals may be less likely in firms with a works council, since the latter increases separation costs for the former. In the case of a works council's objection to a dismissal, an employee is entitled to continue working until a judicial decision or a settlement has been reached. In addition to court costs, for the employer judicial decisions may include severance payments for affected employees. These considerations hint at higher separation costs in those firms with a works council. Therefore, an employer may tend to abstain from a dismissal in such an environment.

Finally, Dilger (2002) and Ellguth (2006) argue that works councils are interested in stable employment relations in order to secure their re-election. Therefore, a works council should act in the interests of the core workforce. Works councils may use their bargaining power derived from codetermination rights in order to keep an employer from dismissing employees. To sum up, the following hypothesis can be stated:

Hypothesis 1: Dismissals are reduced by works councils.

A works council cannot force an employee to stay in a firm, since works councils do not have veto rights concerning voluntary quits. However, a works council may affect voluntary quits 
indirectly. Various considerations are feasible, indicating a negative correlation between works councils and voluntary quits:

Analogously to unions (see Freeman and Medoff, 1984), works councils act as a collective voice institution in the sense of Hirschman (1970). This enables employees to express their dissatisfaction with certain working conditions rather than quitting their jobs. If the employer is interested in such decentral information, and thus in adjusting the working conditions with respect to employees’ preferences, employees’ job satisfaction increases. This may lead to lower voluntary quit rates.

Works councils may also play an important role in fostering trust and cooperation between employer and employees (Addison et al., 2001; Frege, 2002; Jirjahn and Kraft, 2007). Communication between the employer and the employees of a firm is deemed to be relevant in at least two ways: First, works council may attenuate opportunistic behaviour and foster trust between employer and employees via the screening of information that is provided by the employer. This is of particular importance in the context of an employer's report with respect to economic difficulties and a higher demand in working effort. Without a works council, employees do not exactly know whether the employer is merely feigning a crisis or whether the firm is exposed to a real threat. Secondly, employees may not reveal information about potential performance-enhancing innovations to the employer if they fear that this information will be used to their disadvantage in terms of job losses or increased workload. However, a works council's right of codetermination as to how to use such information can impede an employer from taking advantage of employees' information in terms of innovative proposals. Summarizing, employees will not increase their effort or cooperate if an employer cannot credibly commit to taking their interests into account. An existing worker representation may foster trust and cooperation between employer and employees and thus, inter alia, employees’ job satisfaction will be increased and voluntary quits reduced.

Additionally, fairness considerations may be relevant. Not only the result of decisions but also the decision-making process is crucial for employees. Respect and appreciation from the employer influence employees’ motivation and job satisfaction positively (Frey et al., 2004; Jirjahn and Tsertsvadze, 2006). An existing works council may therefore lead to an increase of procedural fairness from the employees' view, an increase in employees' job satisfaction and a reduced voluntary quit rate. To sum up, the following hypothesis can be derived: 
Hypothesis 2: Employee quits are reduced by works councils.

If works councils are negatively associated with both dismissals and voluntary quits by employees, the question arises as to whether certain groups of employees benefit more than others from the presence of a works council. Sex differences as well as employees' occupational status will be examined more closely.

Some arguments hint at the fact that works councils are more inclined to represent the interests of male employees (Hirsch et al., 2010). First, their share of the workforce is traditionally higher than that of women is. Hübler \& Jirjahn (2003) as well as Addison et al. (2003) show that an increasing share of men in an establishment is positively associated with the probability of a works council's existence. Second, works councils members are, for the most part, men. The share of male works councilors is even higher than their employment share. Following the similarity-attraction paradigm (Byrne, 1971), works councils support employees with similar characteristics and therefore use their rights to reduce the number of dismissals of men rather than those of women.

With respect to voluntary quits, both men and women may benefit from a works council's existence. As mentioned above, works councils are more inclined to represent the interests of male employees. In the sense of a collective voice, works councils may get involved for the benefit of men, and therefore male employees will more likely abstain from leaving a firm voluntarily. However, works councils may also reduce voluntary quits by female employees. Many studies show that a works council correlates negatively with a gender wage gap (Gartner and Stephan, 2004; Heinze and Wolf, 2010; Addison et al., 2010). Hence, works councils foster equal treatment of male and female employees and limits potential wage discrimination within a firm. If women experience greater wage fairness as one possible reason, their intention to voluntarily leave a firm will also be reduced.

Hypothesis 3: Dismissals and works councils are negatively related for men in particular. There are no sex differences with regard to voluntary quits. 
Taking employees' occupational status into account, a negative correlation between works councils and dismissals for blue collar workers may particularly be expected. If the workforce of a firm is characterized by a large heterogeneity concerning job conditions and interests, it will be difficult for a works council to balance all interests. Since blue collar workers exhibit similar job conditions and workload, it might be less difficult for a works council to represent their interests to the management (Jirjahn and Tsertsvadze, 2006). Besides, executive white collar employees are not covered by the WCA.

Similar considerations may be relevant regarding the relationship between works councils and voluntary quits by blue collar workers. Direct communication with the management and decision participation are more difficult for blue collar workers. An existing works council will improve this situation and will get involved for the benefit of this subgroup of employees. This may lead to procedural fairness from a blue collar worker's point of view. Pfeifer (2007) argues that works councils support blue collar workers by fostering contacts with supervisors. Works councils may even be helpful with bargaining issues. Moreover, works councils have codetermination rights concerning working time regulations for shift working, which are particularly relevant for blue collar workers. These considerations lead to

Hypothesis 4: The relation of dismissals as well as quits and works councils is particularly negative for blue collar workers.

Finally, works councils do not have direct rights concerning severance payments for individually dismissed employees. However, they may use their extensive bargaining power indirectly to support affected employees and make the receipt of a severance payment more likely. In particular, individuals with bad future job prospects may suffer from income risks due to unemployment. A severance payment can be interpreted as temporary financial compensation fostered by a works council. 


\section{Data, Variables and Methodology}

The analysis in this contribution is based on data from the German Socio-Economic Panel (GSOEP). Within the survey, individuals are asked about their demographics and employment situation in detail. They also have to respond to questions with respect to employment changes and severance payments as a consequence of certain types of separation. Employees are asked about the existence of a works council in their firms only for the years 2001 and 2006 in the GSOEP. We restrict our sample to full- and part-time employees between 18 and 65 years of age who work in private-sector firms with five or more employees. Civil servants are excluded from the analysis. In contrast to previous studies concerning works councils and separations, the GSOEP allows a clear differentiation between dismissals and voluntary quits. ${ }^{3}$ Within the wave of 2002 (2007), respondents are asked whether they have left their job since the beginning of the year 2001 (2006) and they have to indicate the reason for the termination of the employment relationship.

We have a sample size of almost 9,000 observations. The vast majority of employees stay in their firms (0.93), whereas some report quits $(0.04, \mathrm{n}=309)$ as well as dismissals $(0.03$, $\mathrm{n}=234$ ). Furthermore, these dismissed employees are asked whether they have received a severance payment or not. Table 1 gives an overview of the descriptive statistics of our data. The main focus is on the existence of a works council, which is used as a dummy variable ( $1=$ yes, $0=$ no). Focusing on the whole sample, the ratio of individuals reporting the existence of a works council in their firm is about 0.58 . The ratio of dismissed employees as well as voluntary movers having a works council is much lower than that of stayers $(0.3$ and 0.4 , respectively).

\footnotetext{
${ }^{3}$ It has to be noted that the GSOEP contains additional information with regard to individual separations. However, other forms of separation, such as mutual agreements, retirements and temporary employment are not the subject of this paper.
} 
In order to determine the association of works councils with individual dismissals as well as voluntary quits, we will also control for individual, job- and firm-based characteristics. These characteristics include years of schooling, dummies for sex, nationality and disability as well as dummies for job status (untrained and semi-trained blue collar workers, trained blue collar workers, foremen, white collar workers with simple tasks, qualified professionals and highly qualified professionals), type of working contract (part-time vs. full-time), industry (5 categories) and firm size (4 categories). Table 1 shows considerable differences between the groups with regards to age, marital status, children in the household, residence in EasternGermany (i.e. federal states that formerly belong to the German Democratic Republic), tenure (in years) or the job status, for instance. 
Table 1: Descriptive statistics

\begin{tabular}{|c|c|c|c|c|c|c|c|c|}
\hline & \multicolumn{2}{|c|}{ Whole Sample } & \multicolumn{2}{|c|}{ Dismissals } & \multicolumn{2}{|c|}{ Voluntary quits } & \multicolumn{2}{|c|}{ Stayer } \\
\hline & Mean & SD & Mean & SD & Mean & SD & Mean & SD \\
\hline Dismissals & 0.03 & & 1 & & 0 & & 0 & \\
\hline Voluntary quits & 0,04 & & 0 & & 1 & & 0 & \\
\hline Works council (dummy, 1=yes) & 0.58 & & 0.30 & & 0.40 & & 0.60 & \\
\hline \multicolumn{9}{|l|}{ Individual characteristics } \\
\hline Age (in years) & 41.55 & 9.81 & 39.00 & 11.07 & 34.88 & 9.00 & 41.87 & 9,70 \\
\hline Disability (dummy, 1=yes) & 0.05 & & 0.03 & & 0.02 & & 0.05 & \\
\hline Marital status (dummy, $1=$ married) & 0.68 & & 0.57 & & 0.54 & & 0.69 & \\
\hline Sex (dummy, $1=$ male) & 0.62 & & 0.59 & & 0.58 & & 0.62 & \\
\hline Children in the household (dummy, $1=y e s$ ) & 0.40 & & 0.31 & & 0.41 & & 0.40 & \\
\hline Nationality (dummy, $1=$ German) & 0.91 & & 0.90 & & 0.91 & & 0.91 & \\
\hline Residence in Eastern-Germany (dummy, 1=yes) & 0.21 & & 0.34 & & 0.17 & & 0.21 & \\
\hline Years of schooling & 12.18 & 2.51 & 11.46 & 2.14 & 12.73 & 2.72 & 12.18 & 2,50 \\
\hline \multicolumn{9}{|l|}{ Job and firm characteristics } \\
\hline Tenure (in years) & 10.53 & 9.16 & 4.16 & 4.96 & 5.25 & 7.81 & 10.92 & 9.18 \\
\hline Employment status (dummy, $1=$ fulltime) & 0.84 & & 0.87 & & 0.82 & & 0.84 & \\
\hline \multicolumn{9}{|l|}{ Job position: } \\
\hline Untrained and semi-trained blue collar workers & 0.17 & & 0.29 & & 0.17 & & 0.18 & \\
\hline White collar workers with simple tasks & 0.11 & & 0.15 & & 0.13 & & 0.10 & \\
\hline Qualified white collar workers & 0.26 & & 0.19 & & 0.26 & & 0.26 & \\
\hline Highly qualified white collar workers & 0.21 & & 0.09 & & 0.25 & & 0.21 & \\
\hline \multicolumn{9}{|l|}{ Firm size: } \\
\hline 5 - 19 employees & 0.18 & & 0.30 & & 0.25 & & 0.17 & \\
\hline 20 - 199 employees & 0.35 & & 0.45 & & 0.40 & & 0.34 & \\
\hline 200 - 1999 employees & 0.24 & & 0.15 & & 0.18 & & 0.25 & \\
\hline $2000+$ employees & 0.23 & & 0.10 & & 0.17 & & 0.24 & \\
\hline \multicolumn{9}{|l|}{ Industry: } \\
\hline Public/Private Services & 0.10 & & 0.08 & & 0.13 & & 0.10 & \\
\hline Construction & 0.08 & & 0.22 & & 0.07 & & 0.07 & \\
\hline Financial/Corporate Services & 0.14 & & 0.12 & & 0.18 & & 0.14 & \\
\hline Retail/Tourism/Transportation & 0.24 & & 0.26 & & 0.34 & & 0.23 & \\
\hline Manufacturing & 0.44 & & 0.32 & & 0.28 & & 0.45 & \\
\hline \multicolumn{9}{|l|}{ Concerns about job security: } \\
\hline Not concerned at all & 0.40 & & 0.37 & & 0.46 & & 0.40 & \\
\hline Somewhat concerned & 0.45 & & 0.42 & & 0.42 & & 0.45 & \\
\hline Very concerned & 0.15 & & 0.21 & & 0.12 & & 0.15 & \\
\hline Observations & 8.757 & & 234 & & 309 & & 8.214 & \\
\hline
\end{tabular}




\section{Empirical results}

We start our analysis with some bivariate comparisons. In our multivariate analysis, we apply a multinomial logit model. The determinants of dismissals and quits are reported compared to the reference group of stayers. Apart from simply analysing the relation of the existence of a works councils and dismissals as well as quits, we also interact the works council dummy with sex and job status (six dummies for blue and white collar jobs).

As a first indicator, the fraction of dismissals of and quits by employees in firms with and without works councils is examined. Table 2 shows that the dismissal rate is considerably lower for employees in a firm with a works council (0.01 compared to 0.05 in firms without a works council). This is also true for voluntary quits (0.02 compared to 0.05$)$ and the differences hold true for both men and women. The differences are somewhat more pronounced for dismissed men. Lower quit and dismissal rates with regard to job position are especially observable for trained blue collar and qualified white collar workers.

Table 2: Fraction of dismissals and of quits by employees in firms with and without works councils

\begin{tabular}{|c|c|c|c|c|c|}
\hline & & \multicolumn{2}{|c|}{ Dismissals } & \multicolumn{2}{|r|}{ Quits } \\
\hline \multirow[t]{2}{*}{ Whole sample } & works council & 0.014 & \multirow{2}{*}{$* * *$} & 0.024 & \multirow{2}{*}{$* * *$} \\
\hline & no works council & 0.046 & & 0.053 & \\
\hline \multirow[t]{2}{*}{ Male } & works council & 0.011 & \multirow{2}{*}{$* * *$} & 0.022 & \multirow{2}{*}{$* * *$} \\
\hline & no works council & 0.051 & & 0.052 & \\
\hline \multirow[t]{2}{*}{ Female } & works council & 0.020 & \multirow{2}{*}{$* * *$} & 0.028 & \multirow{2}{*}{$* * *$} \\
\hline & no works council & 0.042 & & 0.054 & \\
\hline \multirow[t]{2}{*}{ Untrained and semi-trained blue collar workers } & works council & 0.032 & \multirow{2}{*}{$* * *$} & 0.030 & \multirow{2}{*}{$* *$} \\
\hline & no works council & 0.070 & & 0.053 & \\
\hline \multirow[t]{2}{*}{ Trained blue collar workers } & works council & 0.010 & \multirow{2}{*}{$* * *$} & 0.014 & \multirow{2}{*}{$* * *$} \\
\hline & no works council & 0.065 & & 0.048 & \\
\hline \multirow[t]{2}{*}{ Foremen } & works council & 0.008 & \multirow{2}{*}{$* *$} & 0.024 & \\
\hline & no works council & 0.036 & & 0.019 & \\
\hline \multirow[t]{2}{*}{ White collar workers with simple tasks } & works council & 0.028 & & 0.030 & \multirow{2}{*}{$*$} \\
\hline & no works council & 0.047 & & 0.054 & \\
\hline \multirow[t]{2}{*}{ Qualified white collar workers } & works council & 0.008 & \multirow{2}{*}{$* * *$} & 0.023 & \multirow{2}{*}{$* * *$} \\
\hline & no works council & 0.039 & & 0.054 & \\
\hline \multirow[t]{2}{*}{ Highly qualified white collar workers } & works council & 0.009 & \multirow{2}{*}{$*$} & 0.031 & \multirow{2}{*}{$* * *$} \\
\hline & no works council & 0.018 & & 0.064 & \\
\hline
\end{tabular}


In the following multivariate analysis, we examine whether these results also hold true when controlling for a number of individual- and job-based characteristics. A multinomial logit approach is applied as mentioned above. It can be argued that the existence of a works council may not only correlate with dismissals and voluntary quits in general, but for men and qualified employees in particular. Hence, the particular relationship between works councils and dismissals as well as voluntary quits for several subgroups of employees is examined by using interaction terms.

The works council variable is the variable of particular interest. The results of model (1) in Table 3 show that works councils are negatively associated with dismissals of as well as with quits by employees. This is in line with hypotheses 1 and 2. Interacting the sex and works council dummy in model (2) shows that the negative relationship of dismissals and works councils is somewhat lower and only significant on the 10 percent level for women. The interaction effect for men is negative as expected, but not statistically significant on a reasonable level. Separate estimations for men and women show a higher significance for men. For the case of voluntary quits, the coefficient of the interaction term is anything but significant. Although we cannot find a significant interaction effect for dismissals, the results at least do not contradict our hypothesis 3.

The particular relationship of works councils and separation rates concerning employees' occupational status is analysed in model (3) of Table 3. Unskilled and semi-skilled blue collar workers without a works council serve as a reference category. There are indeed some differences between jobs. The negative relationship both for dismissals and quits is especially pronounced for trained blue collar workers as well as for qualified white collar employees. Therefore, the results are, at most, only partly in line with hypothesis 4 . Works councils may not just care for the interests of the group of blue collar employees, but also worry about qualified employees, who are regarded as success factors of firms. The subgroup of highly qualified professionals is not affected in particular. This is not surprising, since the interests of highly qualified professionals are not included in works councils’ tasks according to §5 (3) of the WCA. 
Table 3: Multinomial logit estimations on dismissals and quits (reference group: stayer)

\begin{tabular}{|c|c|c|c|c|c|c|}
\hline & & (1) & & & & \\
\hline & Dismissals & Quits & Dismissals & Quits & Dismissals & Quits \\
\hline Works council (dummy, 1=yes) & $-0.672^{* * *}(0.171)$ & $-0.386 * *(0.146)$ & $-0.436 *(0.231)$ & $-0.372 *(0.209)$ & $-0.293(0.268)$ & $-0.103(0.298)$ \\
\hline Works council * Male & & & $-0.421(0.302)$ & $-0.024(0.250)$ & & \\
\hline $\begin{array}{l}\text { Works council * Trained blue collar workers } \\
\text { Works council * Foremen/teamleaders } \\
\text { Works council * White collar workers with simple tasks } \\
\text { Works council * Qualified white collar workers } \\
\text { Works council * Highly qualified white collar workers }\end{array}$ & & & & & $\begin{array}{l}-0.935 * *(0.443) \\
-0.310(0.870) \\
-0.018(0.467) \\
-0.999 * *(0.456) \\
0.034(0.525)\end{array}$ & $\begin{array}{l}-0.719 *(0.430) \\
0.583(0.750) \\
-0.411(0.458) \\
-0.383(0.370) \\
-0.199(0.378)\end{array}$ \\
\hline Sex (dummy, 1=male) & $-0.182(0.178)$ & $0.082(0.151)$ & $-0.036(0.205)$ & $0.094(0.184)$ & $-0.171(0.176)$ & $0.090(0.151)$ \\
\hline Age (in years) & $-0.138 * *(0.054)$ & $-0.110 * *(0.050)$ & $-0.139 * *(0.054)$ & $-0.110 * *(0.050)$ & $-0.103 * *(0.054)$ & $-0.112^{* *}(0.051)$ \\
\hline Age-squared*100 & $0.169 * *(0.001)$ & $0.082(0.001)$ & $0.171^{* *}(0.001)$ & $0.082(0.001)$ & $0.169 * * *(0.001)$ & $0.084(0.001)$ \\
\hline Disability (dummy, 1=yes) & $-0.283(0.381)$ & $-0.475(0.422)$ & $-0.284(0.382)$ & $-0.475(0.423)$ & $-0.283(0.381)$ & $-0.466(0.423)$ \\
\hline Marital status (dummy, $1=$ married) & $-0.073(0.166)$ & $0.053(0.139)$ & $-0.072(0.167)$ & $0.053(0.140)$ & $-0.082(0.166)$ & $0.059(0.141)$ \\
\hline Children in the household (dummy,1=yes) & $-0.407 * * *(0.155)$ & $-0.005(0.135)$ & $-0.402 * *(0.155)$ & $-0.005(0.135)$ & $-0.411^{* * *}(0.155)$ & $-0.012(0.136)$ \\
\hline Nationality (dummy, 1=German) & $0.136(0.244)$ & $0.113(0.222)$ & $0.140(0.243)$ & $0.113(0.222)$ & $0.173(0.242)$ & $0.125(0.222)$ \\
\hline Residence in Eastern-Germany (dummy, $1=y e s$ ) & $-0.119(0.153)$ & $-0.475^{* * *}(0.167)$ & $0.014(0.153)$ & $-0.475^{* * * *}(0.167)$ & $0.009(0.153)$ & $-0.478^{* * *}(0.167)$ \\
\hline Years of schooling & $-0.067(0.043)$ & $0.067 * *(0.032)$ & $-0.066(0.043)$ & $0.067 * *(0.032)$ & $-0.071(0.043)$ & $0.078 * *(0.032)$ \\
\hline Tenure (in years) & $-0.088 * * *(0.197)$ & $-0.121^{* * *}(0.181)$ & $-0.088^{* * *}(0.197)$ & $-0.121^{* * *}(0.018)$ & $-0.088 * * *(0.021)$ & $-0.122 * * *(0.018)$ \\
\hline Employment status (dummy,1=fulltime) & $0.268(0.237)$ & $-0.217(0.216)$ & $0.264(0.237)$ & $-0.122(0.187)$ & $0.275^{* *}(0.236)$ & $-0.031(0.188)$ \\
\hline Job position (base category: untrained and semi-trained & ar workers) & & & & & \\
\hline Trained blue collar workers & $-0.369 *(0.198)$ & $-0.217(0.216)$ & $-0.374(0.211)$ & $-0.218(0.216)$ & $-0.080(0.247)$ & $0.057(0.271)$ \\
\hline Foreman/teamleader & $-0.616(0.393)$ & $-0.162(0.388)$ & $-0.631(0.410)$ & $-0.164(0.388)$ & $-0.485(0.466)$ & $-0.428(0.558)$ \\
\hline White collar workers with simple tasks & $-0.195(0.244)$ & $-0.336(0.232)$ & $-0.186(0.243)$ & $-0.335(0.232)$ & $-0.149(0.291)$ & $-0.172(0.291)$ \\
\hline Qualified professional & $-0.435 *(0.226)$ & $-0.253(0.209)$ & $-0.436 *(0.226)$ & $-0.253(0.209)$ & $-0.105(0.264)$ & $-0.084(0.263)$ \\
\hline Highly qualified professional/managerial position & $-0.640 * *(0.307)$ & $0.011(0.253)$ & $-0.648 * *(0.307)$ & $0.009(0.253)$ & $-0.667 *(0.387)$ & $0.091(0.310)$ \\
\hline Firm size (base category: 5-19 employees) & & & & & & \\
\hline 20 - 199 employees & $0.036(0.173)$ & $0.062(0.157)$ & $0.032(0.173)$ & $0.061(0.157)$ & $0.050(0.173)$ & $0.070(0.157)$ \\
\hline 200 - 1999 employees & $-0.122(0.246)$ & $-0.113(0.206)$ & $-0.123(0.246)$ & $-0.113(0.206)$ & $-0.091(0.249)$ & $-0.107(0.207)$ \\
\hline$>=2000$ employees & $-0.339(0.285)$ & $-0.176(0.219)$ & $-0.341(0.286)$ & $-0.176(0.219)$ & $-0.311(0.289)$ & $-0.166(0.218)$ \\
\hline Concerns about job security (Base category: no & & & & & & \\
\hline Somewhat concerned & $0.601^{* * *}(0.180)$ & $0.010(0.132)$ & $0.602 * * *(0.181)$ & & & \\
\hline Very concerned & $1.463 * * *(0.198)$ & $-0.078(0.202)$ & $1.461 * * *(0.197)$ & $-0.077(0.202)$ & $1.464 * * *(0.198)$ & $-0.075(0.202)$ \\
\hline Year 2001 (dummy, 1=yes) & $0.390 * *(0.152)$ & $0.261^{* *}(0.132)$ & $0.394^{* *}(0.152)$ & $0.262^{* *}(0.132)$ & $0.402 * * *(0.153)$ & $0.261^{* *}(0.132)$ \\
\hline Industry dummies & Yes & Yes & Yes & Yes & Yes & Yes \\
\hline Intercept & $-0.106(1.186)$ & $0.032(0.967)$ & $-0.166(1.191)$ & $-0.080(0.983)$ & $-0.260(1.187)$ & $-0.086(0.975)$ \\
\hline Number of observations & & 757 & & 57 & & \\
\hline Pseudo R & & 139 & & 39 & & 42 \\
\hline
\end{tabular}

Notes: Robust standard errors in parentheses; * significant at 10\%; ** significant at 5\%; *** significant at $1 \%$. 
In addition, further control variables are also significantly associated with dismissals and voluntary quits. The results are mostly as expected: The probability of both dismissals and voluntary quits is negatively associated with age and tenure. Dismissals are less likely for employees with children in the household. Employees with higher schooling degrees quit more often and employees in Eastern Germany less. Concerns about job security act as a proxy for the economic situation of firms. Not surprisingly, dismissals are positively associated with these concerns. The results with respect to the works councils dummy do not depend on implementing the set of concerns dummies. However, the negative relationship between works councils and dismissals is particularly relevant for those employees who report a bad economic situation of their firm. Separate estimations of firm size categories show a slightly more pronounced relationship in small-l and medium-sized firms.

As mentioned above in section 2, firms may provide a severance payment to dismissed employees either voluntarily or mandatorily due to an (impending) court ruling. The GSOEP data also contain information on severance payments for dismissed employees. Figure 1 revisits our sample structure and complements it by the fraction and amount of severance payments for dismissed employees of firms with and without works councils. Since absolute numbers are small, we stick to a descriptive analysis here. Remember that the fraction of dismissals for employees in firms without a works council is three times higher than in firms with a works council. The existence of a works council also tends to result in a larger fraction of severance payments in cases of dismissal ( 0.25 compared to 0.14 for dismissed employees in firms without a works council). Given that a severance payment is provided, the median amount is about five times larger for employees of firms with works councils. In the majority of German cases, severance payments are paid in relation to previous years of tenure in the firm and the gross monthly wage (see Jahn 2005, Grund 2006, Goerke \& Pannenberg 2010b). Then, so-called severance pay factors, defined by the amount of the payment divided by the product of the previous wage and years of tenure, can be calculated. Severance pay factors are slightly higher for dismissed employees in firms with a works council. The figure reports medians of severance pay (factors). The relations hold also for other percentiles. These results hint at first evidence for the assumption that works councils are also related to higher relevance of severance payments. This adds to the relationship of the presence of unions and severance payment reported by Goerke \& Pannenberg (2010a). But of course, much more 
research with more comprehensive data is necessary to confirm our assumption with respect to works councils.

Figure 1: Sample structure - works councils, dismissals and severance payments

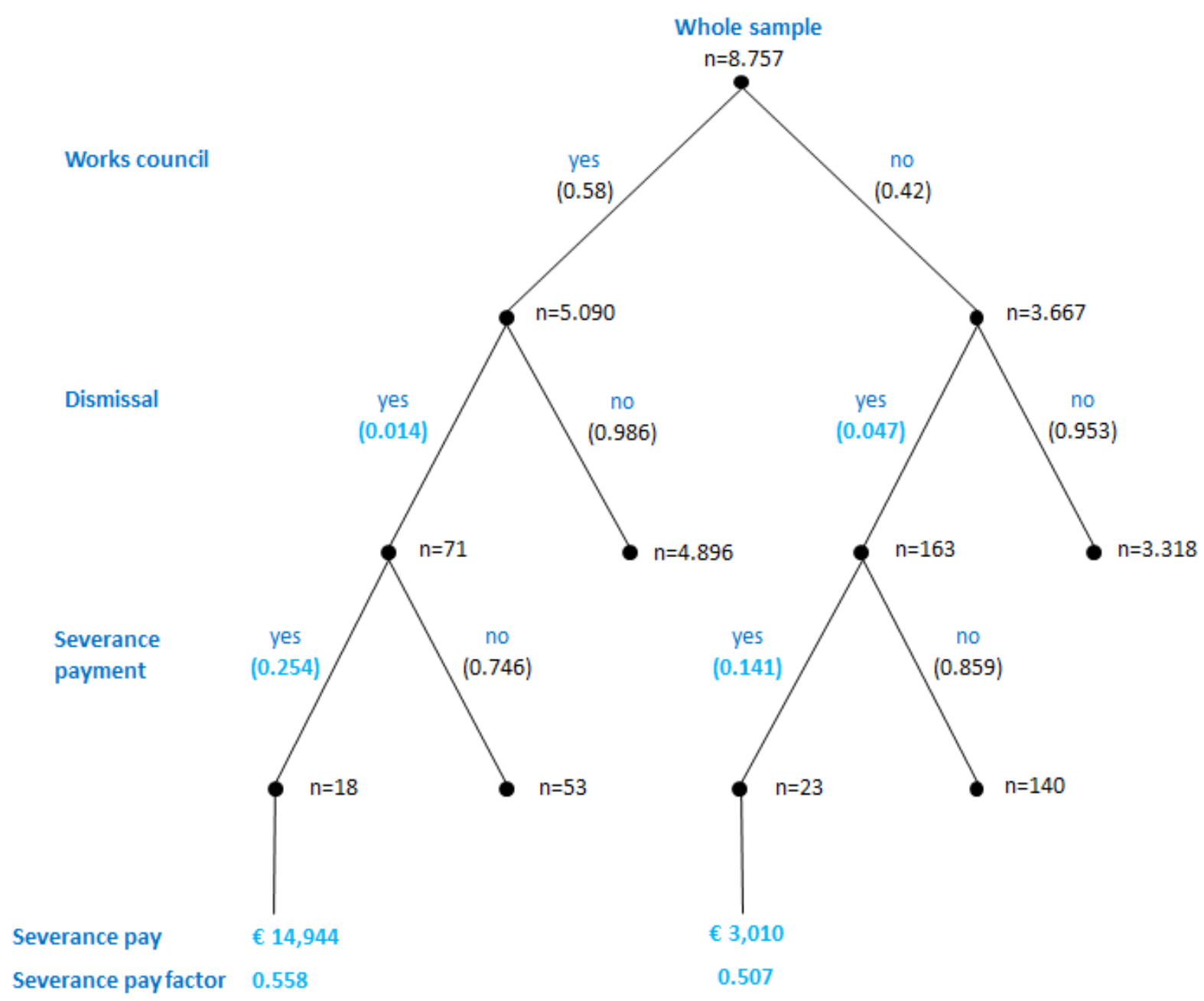

Note: Median of respective severance payments and severance pay factors. Severance pay factor $=$ Amount of severance pay / (Years of tenure * Gross monthly wage). 


\section{Conclusion}

Using a large representative sample of employees in Germany, the relationship between works councils and employment separations is examined. Additionally, the role of severance payments for dismissed employees is addressed. Since works councils may affect certain groups of employees in particular, subgroups with respect to gender and occupational status are analysed. In contrast to previous studies concerning personnel turnovers, the data allow for a clear distinction between dismissals and voluntary quits.

The results provide empirical evidence that works councils are negatively associated with employees' dismissals. Taking a closer look at certain subgroups, we find, at most, slight hints for the conjecture that men benefit more than women from the presence of a works council concerning protection against dismissals. Moreover, dismissals of both trained blue collar workers and qualified white collars are negatively associated with the presence of a works council. Works councils are also found to be negatively related to voluntary quits in general. There are no gender differences. Again, the relationship is particularly pronounced for trained blue collar workers and qualified white collar employees. We find first hints that works councils are also related to the relevance of severance payments in the case of dismissals.

There are some limitations to our contribution due to data restrictions. Future research may address the behaviour of works councils in more detail and examine the interplay between the collaboration of works councils and the firms' management and types of employment separation. We do not have information about the reason for a dismissal, either. The behaviour of a works council might differ considerably when facing a dismissal on account of redundancy compared to a dismissal on grounds of misconduct, e.g. alcohol misuse during working time. It would be beneficial to have this information in order to derive causal effects of works councils on dismissals and severance payments in depth. 


\section{References}

Addison, J. T., Schnabel, C. and Wagner, J. (2001) Works councils in Germany: their effects on establishment performance, Oxford Economic Papers 53, 659-694.

Addison, J. T., Bellmann, L., Schnabel, C. and Wagner, J. (2003) German works councils old and new: incidents, coverage and determinants, Schmollers Jahrbuch 123, 339-358.

Addison, J. T., Teixeira, P. and Zwick, T. (2010) German works councils and the anatomy of wages, Industrial and Labor Relations Review 63, 247-270.

Backes-Gellner, U., Frick,B. and Sadowski, D. (1997) Codetermination and personnel policies of German firms: the influence of works councils on turnover and further training, The International Journal of Human Resource Management 8, 328-347.

Beckmann, M., Föhr, S. and Kräkel, M. (2010) Rent seeking, employment security, and works councils: theory and evidence for Germany, Schmalenbach Business Review 62, 2-40.

Boockmann, B. and Steffes, S. (2010) Workers, firms, or institutions: what determines job duration for male employees in Germany?, Industrial and Labor Relations Review 64, 109127.

Byrne, D. (1971) The attraction paradigm, New York.

Dilger, A. (2002) Ökonomik betrieblicher Mitbestimmung: die wirtschaftlichen Folgen von Betriebsräten, München und Mering.

Ellguth, P. (2006) Betriebsräte und betriebliche Personalfluktuation, in: Buscher, H.S., Dreger, C. and Walwei, U. (ed.) Institutionen und Arbeitsmarkt. Messkonzepte, Wirkungszusammenhänge und internationaler Vergleich (Beiträge zur Arbeitsmarkt- und Berufsforschung) 304, 189-211.

Freeman, R. B. and Medoff, J. (1984) What Do Unions Do?, Basic Books, New York.

Frey, B., Benz, M. and Stutzer, A. (2004) Introducing procedural utility: not only what, but also how matters, Journal of Institutional and Theoretical Economics 160, 377-401.

Frege C. M. (2002) A Critical Assessment of the Theoretical and Empirical Research on German Works Councils, British Journal of Industrial Relations 40, 221-248.

Frick, B. (1996) Co-determination and Personnel Turnover: The German Experience, Labour 10, 407-430.

Frick, B. and Möller, I. (2003) Mandated Works Councils and Firm Performance: Labor Productivity and Personnel Turnover in German Establishments, Schmollers Jahrbuch 123, 423-454.

Gartner, H. and Stephan, G. (2004) How collective contracts and works councils reduce the gender wage gap, IAB Discussion Paper No. 200407.

Goerke, L. and Pannenberg, M. (2010a) Trade union membership and dismissals, IZA Discussion Paper No. 5222, 1-28.

Goerke, L. and Pannenberg, M. (2010b) An economic analysis of dismissal legislation: Determinants of severance payments in West Germany, International Review of Law and Economics 30, 71-85. 
Grund, C. (2006) Severance payments for dismissed employees in Germany, European Journal of Law and Economics 22, 49-71

Grund , C. and Schmitt, A. (2013) Works councils, wages and job satisfaction, Applied Economics 45, 299-310.

Heinze, A. and Wolf, E. (2010) The intra-firm gender wage gap: a new view on wage differentials based on linked employer-employee data, Journal of Population Economics 23, 851-879.

Hirsch, B., Schank, T. and Schnabel, C. (2010) Works councils and separations: voice, monopoly, and insurance effects, Industrial Relations 49, 566-592.

Hirschman, A. (1970) Exit, Voice and Loyality. Responses to Decline in Firms, Organizations and States, Harvard University Press, Cambridge, MA.

Hübler, O. and Jirjahn U. (2003) Works councils and collective bargaining in Germany: the impact on productivity and wages, Scottish Journal of Political Economy 50, 471-491.

Jahn, E. (2005) Wie wirkt der Kündigungsschutz?, Zeitschrift für ArbeitsmarktForschung, 284-304.

Jirjahn, U. (2009) The introduction of works councils in German establishments - rent seeking or rent protection?, British Journal of Industrial Relations 47, 521-545.

Jirjahn, U. (2010) Works councils and employment growth in German establishments, Cambridge Journal of Economics 34, 475-500.

Jirjahn, U. and Tsertsvadze, G. (2006) Betriebsräte und Arbeitszufriedenheit, Jahrbücher für Nationalökonomie und Statistik 226, 537-561.

Jirjahn, U. and Kraft, K. (2007) Intra-firm wage dispersion and firm performance - is there a union relationship?, Kyklos 60, 231-253.

Kraft, K. and Lang, J. (2008) The causes and consequences of adopting a works council, Jahrbücher für Nationalökonomie und Statistik 228, 512-532.

Lazear, E.P. (1979) Why is there mandatory retirement?, Journal of Political Economy 87, 1261-1284.

Lazear, E.P. (1981) Agency, earnings profiles, productivity, and hours restrictions, American Economic Review 71, 606-620.

Pfeifer, C. (2007) Betriebsräte, Tarifverträge und freiwillige Kündigungen von Arbeitnehmern, WSI Mitteilungen 60, 63-69.

Pfeifer, C. (2010) Determinants of promotions in an internal labour market, Schmalenbach Business Review 62, 342-358.

Wagner, J., Schank, T., Schnabel, C. and Addison, J. T. (2006) Works councils, labor productivity and plant heterogeneity: first evidence from quantile regressions, Jahrbücher für Nationalökonomie und Statistik 226, 505-518.

Zwick, T. (2004) Employee participation and productivity, Labour Economics 11, 715-740. 